\title{
Development and productivity of timothy (Phleum pratense L.)
}

\author{
Seppo Pulli \\ University of Helsinki, Dept. of Plant Husbandry, 00710 Helsinki 71
}

\begin{abstract}
The research series on the growth and development of timothy was comprised of a comparison between the three most important timothy varieties in Finland, Tammisto, Nokka and Tarmo in different parts in Finland. The second part of the investigation involved the greenhouse study of the development of the same three varieties together with the northern type Norwegian variety Engmo and southern type Swedish line Sv. 0873.

The development and growth of the three Finnish timothy varieties had similar dry matter and protein production capabilities. The Tammisto variety exhibited rather demanding requirements for growth factors and had regression coefficients greater than one for both dry matter and protein production. The Nokka variety can be classified as a general variety on the basis of its dry matter production, and a well thriving variety with a low level of growth factors on the basis of its raw protein production. The Nokka regression coefficients were approximately one and less than one for dry matter and protein production respectively. The Tarmo variety in regard to energy and protein production is considered a modest variety which had the lowest regression coefficient of the three varieties.

Tarmo variety and Svalöv line Sv. 0873 had exceptionally slow primary development. In later growing stages, however, these same two varieties developed faster than the others. The regrowth capabilities of the Sv. 0873 line and the Engmo variety were weaker than those of the Finnish varieties. The Engmo variety, suited for northern conditions, had the largest root production whereas Sv. 0873, bred for southern conditions, had the weakest. The Engmo variety's large root production promoted fast LAI development. Seeding depth had significance only in the first cutting. The size of the regrowth yield was primarily influenced by the size of the previous cutting. The yields of consecutive cuttings were negatively correlated.
\end{abstract}

\section{Introduction}

Finland is located on the outer edge of the marginal zone for plant production. A short growing season, relatively low average daily temperatures and frequently occurring late summer rains indicate that Finland does not belong to the actual cereal growing region. On the other hand, long days, sufficient amounts of light, the economical water utilization of forage crops and relatively favorable temperatures make Finland ideal for forage crop production. 
The most important forage crop in Finland is timothy. Because of its good winter hardiness it is grown throughout the entire country, even in northern Lapland. The long days and abundant incoming radiation of the Finnish growing season speed up timothy's development. Timothy tolerates the early summer dryness rather well and is not too sensitive to the autumn rains. Timothy has only modest requirements as to soil types, and its growth declines essentially only below the $\mathrm{pH} 5.0$ level.

The dry matter and raw protein production capabilities of different timothy varieties have been published in innumerable studies. Because it is apparent that timothy, as the best wintering forage crop, would remain as Finland's most important forage hay, it is considered necessary to collect the research results of different institutes and compare the yield producing capabilities of the most important timothy varieties over long periods of time. At the same time, with greenhouse experiments, it will be attempted to determine the growth and development rhythms from seeding to the second cutting for the most important domestic and two foreign timothy varieties.

\section{Literature rewiew}

The primary development of timothy:

Timothy germinates better at relatively low temperatures $\left(15-20^{\circ} \mathrm{C}\right)$ than at high ones $\left(25-30^{\circ} \mathrm{C}\right.$ ) (LAnger 1972). In MultamäkI's studies (1962) germanation did not occur at $0^{\circ} \mathrm{C}$, while $10 \%$ of the seeds germinated at $4^{\circ} \mathrm{C}$ in 46 days. When the temperature was $8^{\circ} \mathrm{C}, 99 \%$ germina in 23 days. The optimum moisture level for timothy germination is $60 \%$ of the field water holding capacity (WILliams 1954). The emergence capability of timothy decreases noticeably when planted deeper than $2 \mathrm{~cm}$. Ahlberg (1964) showed that at planting depths of $1 \mathrm{~cm}, 2 \mathrm{~cm}$ and $3 \mathrm{~cm}$ the reduction in emergence was $2 \%, 13 \%$ and $22 \%$ respectively as compared to surface seeding. In practice, however, surface seeding does not produce as good results as when seeding at a depth of $0.5-1.5 \mathrm{~cm}$ (MOORE 1943).

The vegetative development of timothy:

Timothy is divided into three categories based on its growing characteristics and means of utilization, a) pasture type, b) medium type and c) hay type. The pasture type plant is short and leafy with good shooting ability and vigorous regrowth. The hay type is tall and stiff with abundantstem formation. The medium type lies between the former two types. The Finnish varieties are closest to the hay type (RAIninko and JuUti 1975).

Timothy produces shoots most abundantly at relatively low temperatures $\left(15-25^{\circ} \mathrm{C}\right)$ with anbundant light. According to Srmola (1962), raising the soil moisture from $20-60 \%$ of the field capacity increased the number of shoots from 1.4 to 7.4 units. All main nutrients increase the number of shoots, nitrogen beeing the most effective. Shoot production of timothy is most 
pronounced in the spring. As the growing season progresses, shooting decreases while regrowth assumes a greater significance than shoot production.

Leaf area index, LAI, is defined to be the total surface area of all photosynthesizing surfaces per unit area. It reflexes the stand's actual production capacity and the dry matter yield of the canopy is primarily defined by LAI (KVET et al. 1971). Raininko (1968) proved that timothy does not tolerate shade well. Consequently, irrigation produces only a slight raise in the LAI value. RAINinko (1968) also showed that the maximum LAI for timothy was achieved at a nitrogen level of $100 \mathrm{~kg} \mathrm{~N} / \mathrm{ha}$, despite that the dry matter production increased with increasing height as additional $\mathrm{N}$-fertilizer was applied. The maximum LAI for timothy is 6.5 (LANGer 1958). At the maximum LAI the prevention of light dispersion in the stand is $95 \%$.

The regrowth capability of timothy is less than that of other forage grasses (VAlle and Virtanen 1932). Better regrowth is achieved when the cutting is done at an early stage of development. Also heavy applications of nitrogen can produce greater regrowth yields from timothy. In Finland, however, foreign timothy varieties have better regrowth capabilities than domestic varieties. On the other hand the regrowth of the domestic varieties Tammisto and Tarmo is less than that of the Nokka variety. The better regrowth ability of Nokka is also noticed at a high level of nitrogen (RAininko 1970). The greatest regrowth of timothy occurs in the first year stand (RAvANTTI and RavantTi 1955). As the crop ages, the regrowth capability decreases.

The yielding ability of timothy:

In northern Finland timothy can be considered as the most reliable cultivated plant (Pohjakallio and Salonen 1956, Huokuna 1970).

In southern Finland red clover has shown to produce the best yields (VALLE 1947). This fact is supported by the study of Ravantwi (1955). According to Ravantti and Ravantti (1955) and Antila (1973) timothy, when compared to other forage crops has succeeded only to a relatively limited extent. In AntILA's investigation (1973) the forage species behaved at various nitrogen levels as follows:

\begin{tabular}{cccccc}
$\mathrm{N} \mathrm{kg} / \mathrm{ha}$ & Reference (timothy & $100)$ & & & \\
\cline { 1 - 3 } & Timothy & $\begin{array}{c}\text { Orchard } \\
\text { grass }\end{array}$ & Fescue & $\begin{array}{c}\text { English } \\
\text { ryegrass }\end{array}$ & Red clover \\
150 & 100 & 124 & 123 & 120 & 104 \\
300 & 132 & 160 & 144 & 162 & 115
\end{tabular}

At low levels of nitrogen timothy produces as much dry matter (DM) as meadow fescue and orchard grass (LAINe 1966, Huokuna 1970). Anothe factor affecting the forage yield is the number of cuttings. LAINE (1966) showed that the yielding ability of timothy, when harvested as hay, was better than that of fescue and orchard grass. However, if cut more frequently for silage use, the yielding capability of timothy was less than the ones for the species mentioned. 
At low level of nitrogen timothy suffered heavily when the number of cuttings was increased from two to three (RAInINko 1968). The timothy yields in Viikki (RAININko 1968) were as follows:

$\begin{array}{ccll}\text { Cutting } & \text { Yield kg DM/ha } & \\ & \text { N kg/ha } & & \\ & 0 & 100 & 200 \\ 2 & 4120 & 7760 & 9240 \\ 3 & 2530 & 5590 & 7100 \\ 4 & 2480 & 4670 & 6490\end{array}$

The highest yield can be achieved with the combined effect of nitrogen and irrigation (North 1961). During the dry summer of 1973 Mela (1975) obtained a $26 \%$ increase in the DM yield of timothy by irrigation $2 \times 30 \mathrm{~mm}$. ELONEN (1974) had even more significant gains with irrigation. In Viikki RAININKo (1968) obtained the following increase in yields with the combined effect of $\mathrm{N}$ and irrigation.

\begin{tabular}{lccc} 
& \multicolumn{2}{c}{ Yield increase $\mathrm{kg} \mathrm{DM} / \mathrm{kg} \mathrm{N}$} & \\
\cline { 2 - 3 } $\mathrm{N} \mathrm{kg} / \mathrm{ha}$ & & No irrigation & Irrigation \\
$100-200$ & $\ldots \ldots \ldots \ldots \ldots$ & 13.6 & 18.0 \\
$200-300$ & $\ldots \ldots \ldots \ldots \ldots$. & 12.5 & 162 \\
$300-400$ & $\ldots \ldots \ldots \ldots \ldots$. & 0.5 & 2.4
\end{tabular}

The best hay yields of timothy are harvested from the first and second years' stand. Keeping a timothy crop for more than three years is not worth while (Mukula 1973). The present day management techniques with heavy amounts of nitrogen and stressing cutting frequency reduce the wintering abilities of timothy and lower the yields as the stand ages. Earlier, timothy was considered as a long lived plant (EsSEN 1913) which could be maintained at full production condition for up to ten years (VALle 1929). In the 1960's at the experimental stations of the Agricultural Research Centre yields were rarely obtained under intensive silage production from stands older than three years (MELA and Järvi 1972).

The raw protein production of timothy:

The raw protein content of timothy at the early stage of development is higher than that of meadow fescue or orchard grass at the same stage (VALle 1947). Ravantti and Ravantti (1955) ordered the most important forage species according to their levels of productivity based on protein yield for the first year under southern Finnish conditions: red clover, white clover, alsike clover, alfalfa, red fescue, rye grass, orchard grass, meadow fescue, timothy and Kentucky blue grass. For the second year crop the order of productivity was: red clover, alfalfa, orchard grass, meadow fescue, red fescue, rye grass, timothy, alsike clover, Kentucky blue grass and white clover. 
Nitrogen fertilization changes the plants' raw protein productivity as LAINE (1966) displayed in his silage crop investigation:

\begin{tabular}{|c|c|c|c|c|c|}
\hline & & kg Protein/ha & & & \\
\hline Plant variety $\mathrm{kg} \mathrm{N} / \mathrm{ha}$ & 0 & 62 & 124 & 248 & 496 \\
\hline timothy ........................... & 214 & 352 & 614 & 1059 & 1184 \\
\hline meadow fescue ................. & 204 & 350 & 633 & 1275 & 1579 \\
\hline orchard grass .................... & 184 & 356 & 634 & 1170 & 1410 \\
\hline red fescue...$\ldots \ldots \ldots \ldots \ldots \ldots$ & 222 & 438 & 751 & 1359 & 1551 \\
\hline Kentucky blue grass ....... & 160 & 338 & 636 & 1058 & 1206 \\
\hline
\end{tabular}

The nitrogen fertilization does not increase only the protein content but the total dry matter yield as well. In this way the protein yield continues to increase even after the increase in DM yield has stopped (SALONEN 1963). The protein yield of timothy can be raised $9-12 \%$ by applying nitrogen $10-$ 20 days before cutting (AnTILA 1976). On the basis of Raininko's study (1968) it is apparent that it is most advantageous for protein production to cut timothy three times during the growing season. As more cuts are made then the nitrogen level must be raised.

Irrigation has proved to have a slightly negative effect on forage yield protein content at a low level of nitrogen and an extremely negative one as the nitrogen level increases. Nevertheless, irrigation has a positive effect on protein yield per surface area unit, because watering increases the total dry matter yield. RaInINko (1970) achieved the best increase in protein yield by irrigation and cutting three times.

In RavantTI's investigation (1965) the protein yield of timothy rose right up to the third production year. In Teitrinen's study (1958) the protein yield rose in the second but then fell in the third production year. RAININKo and JuUti (1975) experienced the second production year to be better than the first. Variations appeared also in three and four year old timothy stands. The high nitrogen level of $300 \mathrm{~kg} \mathrm{~N} / \mathrm{ha}$ produced abundant increases in the protein yields among stands kept in production 3 or 4 years.

\section{Materials and methods}

The investigation of the growth and development of timothy was divided into two parts, a productivity comparison of the three most important timothy varieties in different parts in Finland and two growth and development studies of five timothy varieties in greenhouse.

The investigated varieties were Tammisto, Tarmo and Nokka. The yielding ability of each variety was compared to the average yield level of the studied varieties in the way described by FinLAY and Wilkinson (1963). For comparisons between the varieties data were collected from studies where the three varieties occured at the same time (KIVEL $\ddot{A}$ 1978). In variety comparisons conducted by the Hankkija Plant Breeding Institute the three varieties have appeared simultaneously 35 times in tests during 1957-70. In the Plant 
Husbandry Institute's tests at Tikkurila the dry matter yields for the three varieties have been measured concurrently 27 times during 1949-76. The dry matter yield tests for the three varieties were carried out 62 times in southern (Hankkija and Tikkurila locations) and 29 times in northern (Lapland Experimental Station) Finland. The comparison of protein yields from the three varieties is based only on 37 tests conducted under southern Finnish conditions (KIVELÄ 1978).

The greenhouse study involving test Series I and II was carried out in summer 1976. In both series the three domestic timothy varieties Tammisto, Tarmo and Nokka were used as test material. The comparative test crops were a Norwegian variety, Engmo, bred for northern conditions and the Swedish timothy line Sv. 0873, which can be considered suitable for southern conditions.

Serie I was seeded in $0.2 \mathrm{~m}^{2}$ plastic boxes with four rows per box. The seeding rate was $20 \mathrm{~kg} / \mathrm{ha}$ and the distance between rows was $12.5 \mathrm{~cm}$. The growing medium was clay with an anbundant amount of organic matter. Watering occurred automatically and the amount of fertilizer applied was $250 \mathrm{~kg} \mathrm{~N} / \mathrm{ha}$. The stands in all eight replications were equally thinned. From each variety one row $(30 \mathrm{~cm})$ was cut when the stand height reached $5,10,15$, $20,25,30$ and $35 \mathrm{~cm}$ respectively. The leaf area index (LAI) and shoot and root yield were measured for each stand. The $24 \mathrm{~h}$ average temperature was $18^{\circ} \mathrm{C}$ and the average relative humidity $50 \%$.

Serie II was planted in round, $0.08 \mathrm{~m}^{2}$ plastic pots. The seeding rate was $20 \mathrm{~kg} / \mathrm{ha}$, and the planting depth was $2 \mathrm{~cm}$ in the first four replications and 4 $\mathrm{cm}$ in the second four. The stands were thinned to 20 plants per pot. The watering was automatic and the fertilization was the same as for Serie I. The stands' growth and development were followed at weekly intervals with 2 measurements per pot. All plants were cut for the first time $\mathbf{5 5}$ days after planting, by which time the tallest variety had reached $65 \mathrm{~cm}$ in height. From the first cutting each stand's height, LAI and shoot dry matter yield were determined.

Regrowth development was followed with weekly height growth measurements. The stands were cut for the second time 34 days after the first cut. From the second cutting the height, LAI and shoot and root dry matter yield for each stand were determined. The drying temperature and time employed in the dry matter measurements were $100^{\circ} \mathrm{C}$ and $24 \mathrm{~h}$ respectively.

\section{Results and discussion}

\section{1. Long term productivity of the three varieties}

\subsubsection{Dry matter production at different yield levels}

Of the Finnish timothy varieties, Tammisto is a Hankkija Plant Breeding Institute improved strain, which came into general use in 1948. Tammisto is a cross between the Swedish Bottnia variety and the local Finnish variety, Haukila (RAvanti 1963). The Jokioinen Plant Breeding Institute timothy 
variety, Tarmo, was developed from southern Finnish material and was put on the market in 1948. The longlivedness of both Tammisto and Tarmo has been rather good under Finnish growing conditions (MANNER et al. 1966). The local strain, Nokka, originates from the Nokka estate in southwest Finland and has been developed trough selection of the best material over the last 80 years.

In the Hankkija Plant Breeding Institute tests for 1927-56 the varieties which had been in tests at least $\mathbf{4 - 5}$ years behaved as follows (RAVANTTI 1960): the local strain Haukila and the timothy variety Tammisto have yielded equally as much as Nokka. The Tarmo variety remained $4 \%$ units below the yield level of Nokka.

All of the foreign varieties in the tests were either at the same level as Tarmo or lower. During $1957-63$ at Hankkija the best Danish varieties proved to equal Nokka and Tarmo, but were $4-9 \%$ units more productive than Tammisto (RavantTi 1965). In the same study the Swedish varieties were 3-18 \% units more productive than Tammisto. On the other hand, the Dutch, English and Canadian varieties that were studied turned out to be less productive than the best Finnish ones.

RAININKo (1970) pointed out that in regard to the productivity of Finnish timothy varieties, Tammisto, Tarmo and Nokka are relatively equal at a low level of nitrogen. At higher nitrogen levels Tammisto exceeds both Tarmo and Nokka in productivity by $11-13 \%$ units.

In the Agricultural Research Center tests conducted on timothy in the 1960's, Tammisto, Tarmo, Nokka, Bodin, Bottnia, Engmo and Sv. 0853 all gave equally high forage yields (MELA and JärVI 1972). Bottnia II and Engmo produced less yield at the southern experimental stations than at the northern one in Rovaniemi. The Canadian variety, Climax, had very poor succes in northern Finland.

The varieties of Nokka, Tarmo and $\mathrm{Hja} 1160$ produced slightly higher yields than the control variety, Tammisto, in the tests carried out at experimental stations during 1968-75 (Mela 1976). Considering silage crop yields, Tammisto, Nokka, Tarmo, Bottnia, Otto, Jo 0166 and $\mathrm{Hja} 1160$ all produced close to the same amount (Mela 1976).

Changes occur in the productivity of timothy varieties as the crop ages. The reasons for these changes are primarily because of different development rhythms and differences in wintering abilities (MELA and JäRVI 1972). Under southern Finnish growing conditions particularly Nokka's productivity increases whereas the productivity of the Canadian variety Climax decreases as the stand ages. Under northern Finnish growing conditions the productivity of the Tarmo, Bodin, Bottnia II, Nokka and Apukka timothy varieties has relatively improved in comparison to the Tammisto variety in regard to stand ageing (JäRvi and MELA 1976).

\section{Results:}

The average yields of the three timothy varieties (Tammisto, Tarmo, Nokka), as studied by Hankkija during $1957-70$ in 35 different field tests, differed from each other by only $230 \mathrm{~kg} \mathrm{DM} / \mathrm{ha}$ (Table 1). The Agricultural Research 
Center tests covering the years 1949-76 came up with exactly the same difference. The average yield for all varieties in southern Finland was $7000 \mathrm{~kg}$ $\mathrm{DM} / \mathrm{ha}$ with the deviation between the varieties' means being only $190 \mathrm{~kg} \mathrm{DM} / \mathrm{ha}$. In northern Finland the varieties produced an average of $1000 \mathrm{~kg} \mathrm{DM} / \mathrm{ha}$ less than in southern Finland (Table 1). The difference among the varieties' means in northern Finland was very small, only $50 \mathrm{~kg}$ DM/ha. The weighted average yields of the three varieties for all of Finland represent a yield level of $6700 \mathrm{~kg}$ $\mathrm{DM} / \mathrm{ha}$. Between the varieties there were no significant differences in yield (Table 1). The fact that the standard deviation of the Tammisto yield was greater than those of the Tarmo and Nokka varieties, at all test sites, (Table 1) points out that, Tammisto is more sensitive to changes in environmental conditions than either Tarmo or Nokka. The regression coefficients for southern and northern Finland and the entire country, based on the test material, are equal and near $b=1$, describing almost the same sensitivities to different

Table 1. Dry matter production coefficient of correlation ( $r$ ) between the timothy variety and the mean of the varieties, slope (b) intercept (a), standard deviation (SDy), mean yield of the variety $(y)$ and variation coefficient of the mean of the variety $(\mathrm{V})$ in different parts of Finland in 1949-1976.

\begin{tabular}{|c|c|c|c|c|c|c|c|}
\hline $\begin{array}{l}\text { Research } \\
\text { Institute }\end{array}$ & Variety & $\begin{array}{l}\text { Correlation } \\
\text { coefficient } \\
\text { r }\end{array}$ & $\begin{array}{c}\text { Inter- } \\
\text { cept } \\
\text { a } \\
\end{array}$ & $\begin{array}{l}\text { Regres- } \\
\text { sion } \\
\text { coeffic. } \\
\text { b }\end{array}$ & $\begin{array}{l}\text { Avg. } \\
\text { yield } \\
\mathrm{kg} / \mathrm{ha} \\
\mathrm{y}\end{array}$ & $\begin{array}{c}\text { Standard } \\
\text { deviation } \\
\text { SDy }\end{array}$ & $\begin{array}{c}\text { Variation } \\
\text { coefficient } \\
\text { V } \\
\end{array}$ \\
\hline $\begin{array}{l}\text { Hankkija } \\
\text { (35 trials) }\end{array}$ & $\begin{array}{l}\text { Tammisto } \\
\text { Tarmo } \\
\text { Nokka }\end{array}$ & $\begin{array}{l}.970^{* * *} \\
.981^{* * *} \\
.978^{* * *}\end{array}$ & $\begin{array}{c}-3.193 \\
4.612 \\
.945\end{array}$ & $\begin{array}{r}1.047 \\
922 \\
1.024 \\
\text { Avg. }\end{array}$ & $\begin{array}{l}7770 \\
7590 \\
7820 \\
7730\end{array}$ & $\begin{array}{l}2193 \\
1903 \\
2125\end{array}$ & $\begin{array}{l}28.2 \\
25.1 \\
27.1\end{array}$ \\
\hline $\begin{array}{l}\text { Agricultural } \\
\text { Research } \\
\text { Centre } \\
\text { Tikkurila } \\
\text { (27 trials) }\end{array}$ & $\begin{array}{l}\text { Tammisto } \\
\text { Tarmo } \\
\text { Nokka }\end{array}$ & $\begin{array}{l}.993^{* * *} \\
.994^{* * *} \\
.993^{* * *}\end{array}$ & $\begin{array}{r}-1.588 \\
-\quad .958 \\
2.485\end{array}$ & $\begin{array}{c}1.043 \\
.995 \\
.961 \\
\text { Avg. }\end{array}$ & $\begin{array}{l}6170 \\
5940 \\
6080 \\
6060\end{array}$ & $\begin{array}{l}1951 \\
1859 \\
1798\end{array}$ & $\begin{array}{l}31.6 \\
31.2 \\
29.5\end{array}$ \\
\hline $\begin{array}{l}\text { Southern } \\
\text { Finland } \\
\text { (62 trials) }\end{array}$ & $\begin{array}{l}\text { Tammisto } \\
\text { Tarmo } \\
\text { Nokka }\end{array}$ & $\begin{array}{l}.981 * * * \\
.988 * * * \\
.986 * * *\end{array}$ & $\begin{array}{c}-1.727 \\
1.671 \\
.086\end{array}$ & $\begin{array}{r}1.034 \\
.957 \\
1.007 \\
\text { Avg. }\end{array}$ & $\begin{array}{l}7070 \\
6880 \\
7050 \\
7000\end{array}$ & $\begin{array}{ll}2 & 226 \\
2 & 046 \\
2 & 157\end{array}$ & $\begin{array}{l}31.4 \\
29.7 \\
30.6\end{array}$ \\
\hline $\begin{array}{l}\text { Lapland } \\
\text { Exp. Station } \\
=\text { Northern Finland } \\
\text { (29 trials) }\end{array}$ & $\begin{array}{l}\text { Tammisto } \\
\text { Tarmo } \\
\text { Nokka }\end{array}$ & $\begin{array}{l}.972^{* * *} \\
.966^{* * *} \\
.975^{* * *}\end{array}$ & $\begin{array}{r}-3.886 \\
-1.151 \\
4.462\end{array}$ & $\begin{array}{c}1.057 \\
1.020 \\
.928 \\
\text { Avg. }\end{array}$ & $\begin{array}{l}5970 \\
6020 \\
6030 \\
6000\end{array}$ & $\begin{array}{l}1530 \\
1486 \\
1341\end{array}$ & $\begin{array}{l}25.6 \\
24.6 \\
22.2\end{array}$ \\
\hline $\begin{array}{l}\text { Average } \\
\text { Finland } \\
\text { (91 trials) }\end{array}$ & $\begin{array}{l}\text { Tammisto } \\
\text { Tarmo } \\
\text { Nokka }\end{array}$ & $\begin{array}{l}.980^{* * *} \\
.984 * * * \\
.94^{* * *}\end{array}$ & $\begin{array}{c}-2.518 \\
1.655 \\
.683\end{array}$ & $\begin{array}{r}1.042 \\
.962 \\
.996 \\
\text { Avg. }\end{array}$ & $\begin{array}{l}6720 \\
6600 \\
6740 \\
6690\end{array}$ & $\begin{array}{l}2086 \\
1919 \\
1986\end{array}$ & $\begin{array}{l}31.0 \\
29.0 \\
29.4\end{array}$ \\
\hline
\end{tabular}

Average varieties $\mathrm{F}=\mathrm{Ns}$ 
environmental factors effecting the yield level. In the investigated environments Tammisto had a regression coefficient greater than 1. Nokka and Tarmo had regression coefficients of 1 and less than one respectively. The regression lines derived from the test material covering the whole country are as follows:

$$
\begin{aligned}
& \text { Y Tammisto }=1.042 \mathrm{x}-2.518 \\
& \mathrm{Y} \text { Tarmo }=0.962 \mathrm{x}+1.655 \\
& \mathrm{Y} \text { Nokka }=0.996 \mathrm{x}+0.683
\end{aligned}
$$

The coefficient of variation (V) was smallest for the northern Finland tests and largest for the Tikkurila tests. The coefficient of variation for the whole country was about $\mathrm{V}=30$ (Table 1 ). There were no significant differences in dry matter production between the varieties.

\subsubsection{Protein production at different yield levels}

On the basis of the Hankkija Plant Breeding Institute studies (RaIninko $1970)$ it appeared that at a low level of nitrogen $(50-150 \mathrm{~kg} \mathrm{~N} /$ ha) Nokka timothy gave as high or even better raw protein yields than Tammisto, but at a high level of nitrogen ( $300 \mathrm{~kg} \mathrm{~N} / \mathrm{ha})$ Nokka produced less. In the same way Tarmo timothy competes well with Tammisto at a low level of nitrogen $(150 \mathrm{~kg}$ $\mathrm{N} / \mathrm{ha}$ ) but falls behind at a high level (300 kg N/ha) (RAINinko and JuUti 1975).

Results:

Comparison of the raw protein production capabilities of the investigated timothy varieties was made difficult because the raw protein content was determined for very few tests. In addition, the tests were comparised of different varieties resulting in a limited amount of material for use in this particular comparison. The material used in the regression analysis for the comparison of protein productivities consisted of, however, 22 tests during 1958-68 and 15 tests during 1949-64 from the Hankkija Plant Breeding Institute and the Agricultural Research Center. Plant Husbandry Institute respectively where the three timothy varieties occurred simultaneously.

The average yields for the timothy varieties, Hankkija $720-740 \mathrm{~kg}$ protein/ ha, Plant Husbandry Institute $450-470 \mathrm{~kg}$ protein/ha and average $610-620$ $\mathrm{kg}$ protein/ha were indexed for all three of the investigated varieties (Table 2).

The standard deviation and coefficient of variation for Tammisto were higher than ones for either Nokka or Tarmo, and indicate the variability of the Tammisto variety as well as its sensitivity to environmental changes. Differences in the regression coefficients for the certain variety between experimental sites can come from differences in the degrees of management intensity (Tables 1 and 2). The overall regression coefficients of varieties in southern Finland illustrate that Tarmo and Nokka varieties thrive well at different yield levels. The regression equations for raw protein productition between the three investigated varieties and the average of the varietis are as follows (Fig. 2): 


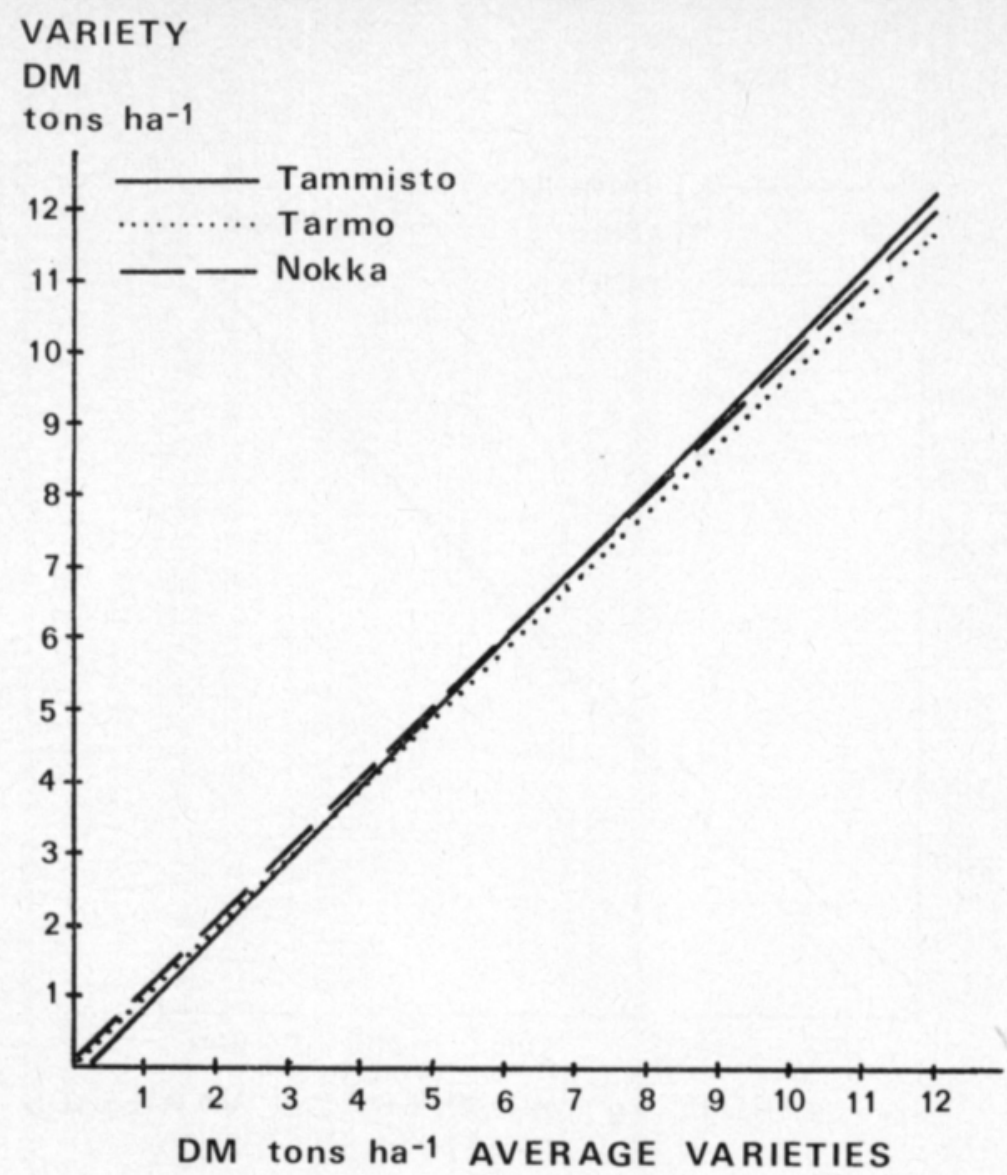

$\begin{array}{ll}\text { Tammisto } & y=1.04 x-2.52 \\ \text { Tarmo } & y=0.96 x+1.66 \\ \text { Nokka } & y=0.99 x+0.68\end{array}$

Fig. 1. The relationship between the dry matter productivity of a variety $\left(\mathrm{kg} \mathrm{DM} \mathrm{ha} \mathrm{h}^{-1}\right.$ ) and the average yield of varieties in 91 timothy variety trials during $1949-76$ in Finland. 


\section{VARIETY}

\section{PROT.}

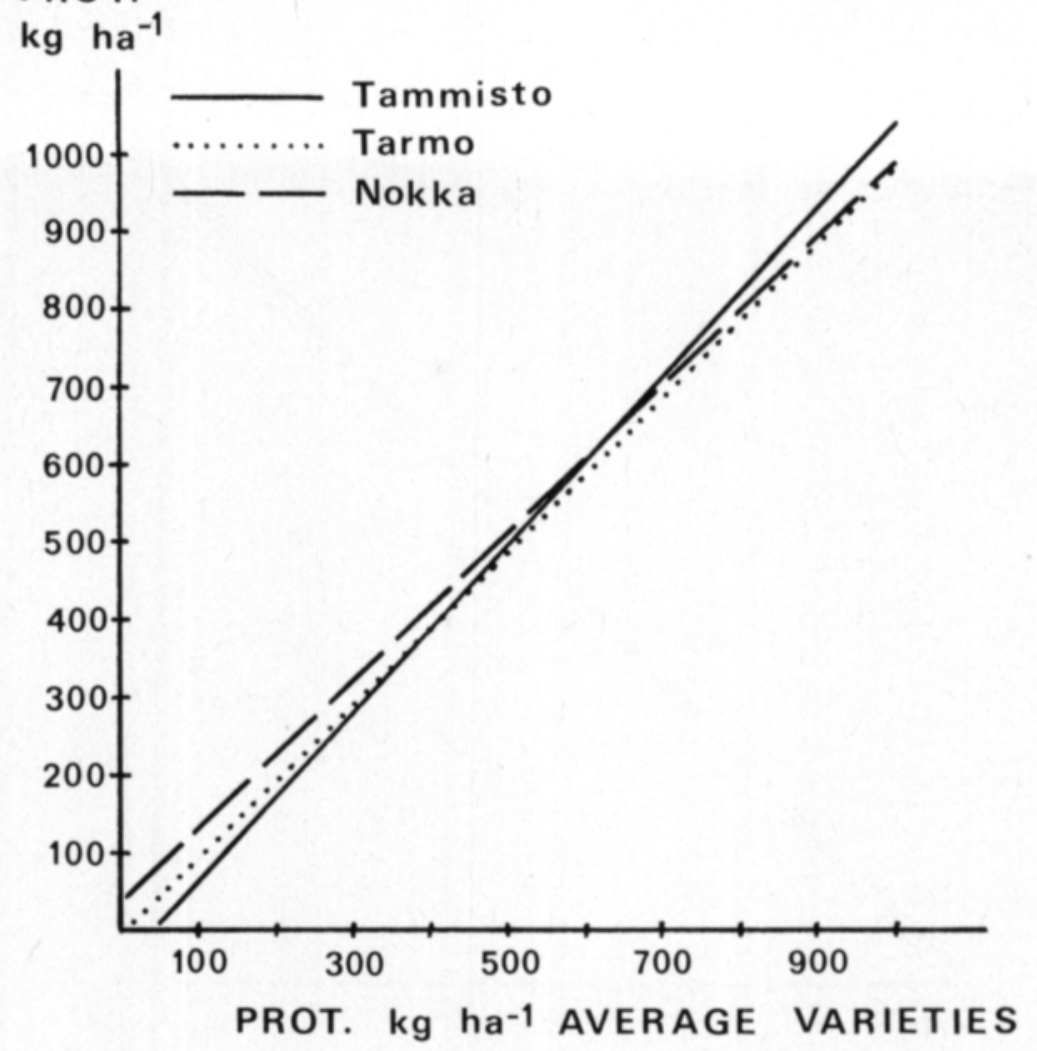
Tammisto $y=1.09 \times-49.1$
Tarmo $\quad y=0.96 x+15.6$
Nokka $\quad y=0.95 x+34.3$

Fig. 2. The relationship between the protein productivity of a vareity (kg prot. ha-1) and the average protein yield of varieties in 37 variety trials during $1958-64$ in Southern Finland. 
Table 2. Protein production coefficient of correlation ( $\mathrm{r}$ ) between the timothy variety and the mean of the varieties, slope (b), intercept (a), standard deviation (SDy), mean yield of the variety $(y)$ and variation coefficient of the mean of the variety $(\mathrm{V})$ in different part of Finland in 1958-1964.

\begin{tabular}{|c|c|c|c|c|c|c|c|}
\hline $\begin{array}{l}\text { Research } \\
\text { Institute }\end{array}$ & Variety & $\begin{array}{c}\text { Correlation } \\
\text { coefficient } \\
\mathrm{r}\end{array}$ & Intercept & $\begin{array}{l}\text { Regres- } \\
\text { sion } \\
\text { coeffic. } \\
\text { b }\end{array}$ & $\begin{array}{c}\text { Avg. } \\
\text { yield } \\
\mathrm{kg} / \mathrm{ha} \\
\text { y }\end{array}$ & $\begin{array}{c}\text { Standard } \\
\text { deviation } \\
\text { SDy }\end{array}$ & $\begin{array}{c}\text { Variation } \\
\text { coefficient } \\
\text { V }\end{array}$ \\
\hline $\begin{array}{l}\text { Hankkija } \\
\text { (22 trials) }\end{array}$ & $\begin{array}{l}\text { Tammisto } \\
\text { Tarmo } \\
\text { Nokka }\end{array}$ & $\begin{array}{l}.987^{* * *} \\
.989^{* * *} \\
.989^{* * *}\end{array}$ & $\begin{array}{r}-8.582 \\
3.772 \\
5.053\end{array}$ & $\begin{array}{c}1.134 \\
.935 \\
.928\end{array}$ & $\begin{array}{l}740 \\
720 \\
730\end{array}$ & $\begin{array}{l}340 \\
280 \\
270\end{array}$ & $\begin{array}{l}45.9 \\
38.8 \\
36.9\end{array}$ \\
\hline $\begin{array}{l}\text { Agricultural } \\
\text { Researeh } \\
\text { Centre } \\
\text { Tikkurila } \\
\text { (15 trials) }\end{array}$ & $\begin{array}{l}\text { Tammisto } \\
\text { Tarmo } \\
\text { Nokka }\end{array}$ & $\begin{array}{l}.984^{* * *} \\
.994^{* * *} \\
.989^{* * *}\end{array}$ & $\begin{array}{r}5.215 \\
-2.434 \\
-2.726\end{array}$ & $\begin{array}{r}.872 \\
1.037 \\
1.089\end{array}$ & $\begin{array}{l}450 \\
450 \\
470\end{array}$ & $\begin{array}{l}140 \\
160 \\
170\end{array}$ & $\begin{array}{l}31.1 \\
35.5 \\
36.1\end{array}$ \\
\hline $\begin{array}{l}\text { Southern } \\
\text { Finland } \\
\text { (37 trials) }\end{array}$ & $\begin{array}{l}\text { Tammisto } \\
\text { Tarmo } \\
\text { Nokka }\end{array}$ & $\begin{array}{l}.987^{* * *} \\
.992^{* * *} \\
.990^{* * *}\end{array}$ & $\begin{array}{r}-4.909 \\
1.557 \\
3.427\end{array}$ & $\begin{array}{r}1.087 \\
.960 \\
.951\end{array}$ & $\begin{array}{l}620 \\
610 \\
620\end{array}$ & $\begin{array}{l}310 \\
270 \\
270\end{array}$ & $\begin{array}{l}50.0 \\
44.2 \\
43.5\end{array}$ \\
\hline
\end{tabular}

Average varieties $\mathrm{F}=\mathrm{Ns}$

$$
\begin{aligned}
& \mathrm{Y} \text { Tammisto }=1.087 \mathrm{x}-4.909 \\
& \mathrm{Y} \text { Tarmo }=0.960 \mathrm{x}+1.557 \\
& \mathrm{Y} \text { Nokka }=0.951 \mathrm{x}+3.427
\end{aligned}
$$

\subsubsection{Discussion}

Timothy variety tests conducted in different years under different conditions provide different results. Because of this the average value calculated for a variety rarely describes for a variety rareley describes the actual characteristics of the variety. For comparisons between varieties the procedure developed by FINLAY and WILKInson (1963) provides the average value with a more reliable base. In the FINLAY and WILKInSON procedure the yielding capability of each variety is compared to the average of all the varieties existing at the same time. The regression coefficient derived shows how a variety functions under different growing conditions. For groups of characteristics were defined by FINLAY and WiLkinson:

1. Thriving varieties: those with a regression coefficient less than 1 .

2. Demanding varieties: those with a regression coefficient greater than 1 .

3. General varieties: those with a regression coefficient approximately 1 and high average yield.

4. Rejected varieties: those with a regression coefficient of approximately 1 and a low average yield.

On the basis of the FInLAY - Wilkinson categories the Tammisto timothy variety represents a demanding variety whose dry matter and raw protein production regression coefficient is greater than 1 and yield level is high. The Nokka variety can be considered general variety for dry matter production and a thriving variety for protein production, which already at a low level of 
nitrogen has good protein production. The Tarmo variety represents a thriving variety for both dry matter and protein production as its regression coefficient is less than 1 and has a relatively high yield level.

According to REKUNEN (1979) the regression coefficient contains mistakes, if the coefficient of deterimination remains low. If the degree of freedom for a test is below 10, only the main features are interpretable. Concerning this investigation the coefficient of determination for each variety was high, indicating that the derived regression equations describe the varieties' characteristics well.

\section{2. Timothy giowth and development in the greenhouse studies}

\section{2. 1. Development of plant height}

In HARI and LeIkola's (1974) study the stand's height growth in the beginning was accelerated. In the second stage height growth is a maximum and continues for a certain time. The third stage is one of a slowed rate ot growth and ends with the plant reaching its greatest height. Of the factors effecting height growth only temperature is of essential significance in Finnish conditions (Olofsson 1962, PohJONEn and Hari 1973, Hari et al. 1977). According to HARI and LeIKola (1974) temperature accounts for 75-96\% of the height growth variation. HAN et al. (1977) claim that the height growth of the forage increases until the point where the light intensity falls below $50 \%$ of full sunlight. According to Heikinheimo (1960) long days shorten the period of vegatative growth and hasten the start of generative growth.

The stem of timothy increases in height evenly up until flowering (SALO 1975). In general, Finnish varieties have significantly longer stems than foreign varieties brought to Finland (Teitrinen 1958). The Hankkija Plant Breeding Institute tests showed no large differences in stem height between domestic timothy varieties (RAVANTTI 1965).

\begin{tabular}{lcccc}
\multicolumn{4}{c}{ Stem height $\mathrm{cm}$} & 1957-63 \\
\cline { 2 - 4 } Variety & year & year 2 & year 3 & x \\
Tammisto & 73 & 83 & 88 & 80 \\
Tarmo & 71 & 84 & 84 & 79 \\
Nokka & 74 & 85 & 89 & 83
\end{tabular}

Results:

Nokka and Engmo had the fastest primary development of the timothy varieties tested in the greenhouse (Fig. 3). The Tammisto variety had very vigorous growth initiation, but decreased relatively as growth progressed. Growth initiation for the Svalöv line Sv. 0.873 was slower than the three test varieties (Tammisto, Tarmo, Nokka) but was noticeably faster than these three varieties in reaching a stand height of $30 \mathrm{~cm}$ (Fig. 4). The greatest height difference in favor of Svalöv's Sv. 0873 can be seen in the first and second cuttings of stands planted at the shallow depth (Table 3). On the three test varieties Tarmo exhibits the most even growth and Tarmo and Tammisto are the shortest ones although the differences between the varieties were few Nokka had the best regrowth (Table 3). 


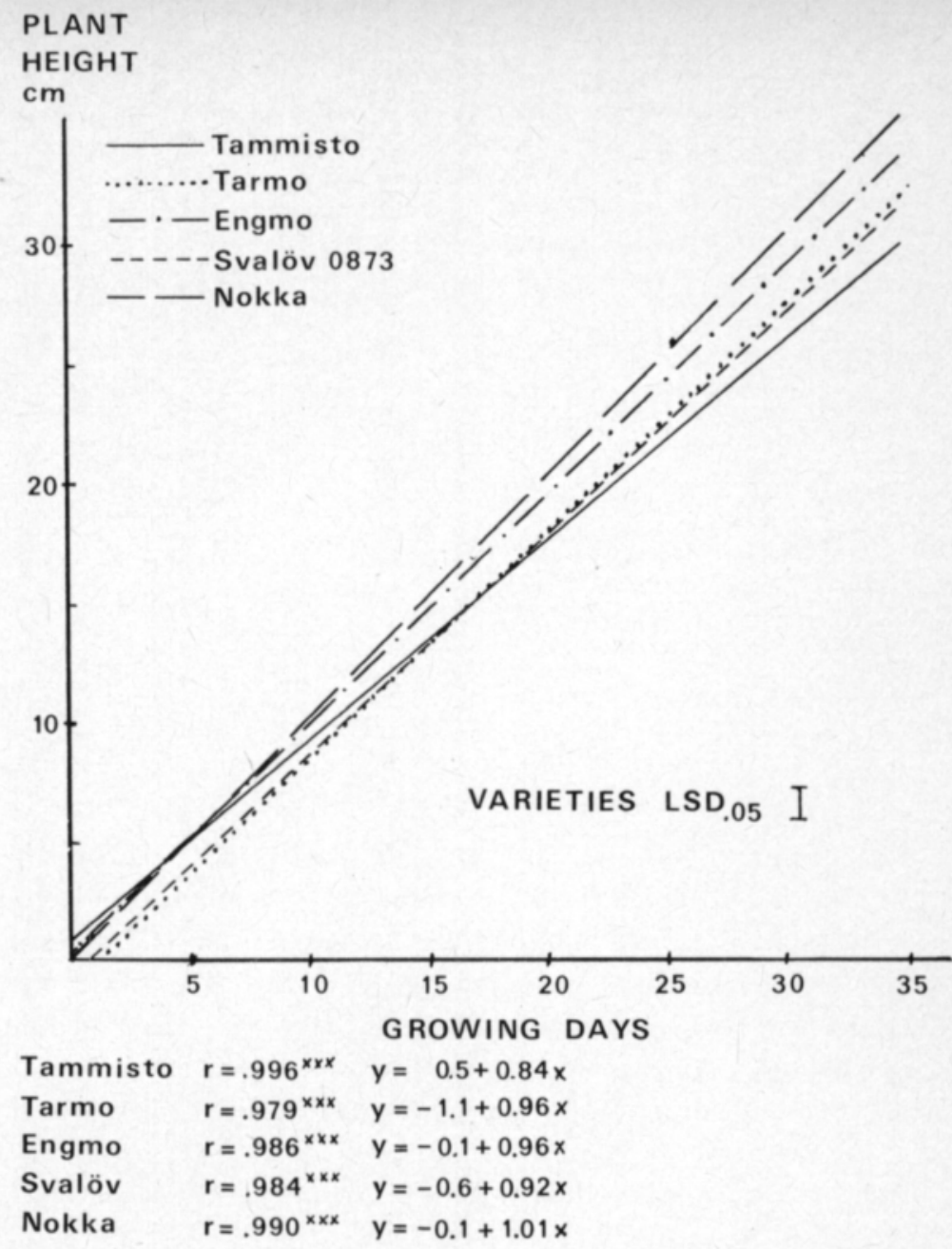

Fig. 3. The relationship between the growing time and the plant height in the early development of five timothy varieties.

\section{SEEDING DEPTH $2 \mathrm{CM}$}

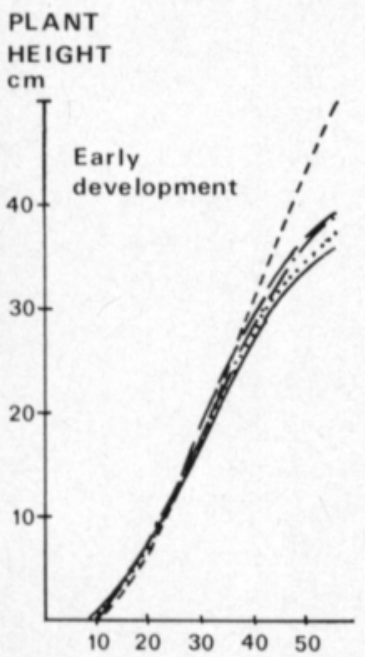

\section{SEEDING DEPTH 4 CM}

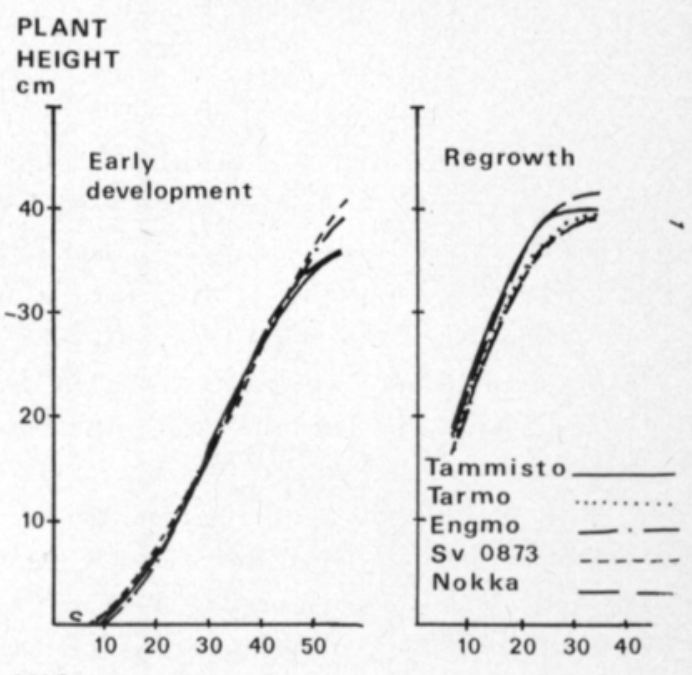

Fig. 4. The plant height development of five timothy varieties between emergence and the first cut and between the first and the second cut seeded at the depths of $2 \mathrm{~cm}$ and $4 \mathrm{~cm}$. 
Table 3. Plant height of five timothy varieties $(\mathrm{cm})$ in the first and second cuts in the greenhouse tests seeded at the depth of $2 \mathrm{~cm}$ and $4 \mathrm{~cm}$.

\begin{tabular}{|c|c|c|c|c|c|c|}
\hline \multirow{3}{*}{ Variety } & \multirow{2}{*}{\multicolumn{3}{|c|}{ Early development }} & \multirow{2}{*}{\multicolumn{3}{|c|}{ Regrowth }} \\
\hline & & & & & & \\
\hline & $2 \mathrm{~cm}$ & $4 \mathrm{~cm}$ & Avg. & $2 \mathrm{~cm}$ & $4 \mathrm{~cm}$ & Avg. \\
\hline Nokka ........ & $38.9 \mathrm{a}$ & $35.8 \mathrm{a}$ & $37.4 \mathrm{a}$ & $37.2 \mathrm{~b}$ & $40.6 \mathrm{a}$ & $38.8 \mathrm{~b}$ \\
\hline Tammisto .... & $35.3 \mathrm{a}$ & $35.4 \mathrm{a}$ & $35.3 \mathrm{a}$ & $31.2 \mathrm{a}$ & $39.3 \mathrm{a}$ & $35.2 \mathrm{a}$ \\
\hline Tarmo ......... & $37.0 \mathrm{a}$ & $36.8 \mathrm{a}$ & $36.9 \mathrm{a}$ & $33.2 \mathrm{ab}$ & $39.1 \mathrm{a}$ & $36.2 \mathrm{ab}$ \\
\hline Engmo ........ & $38.9 \mathrm{a}$ & $38.4 \mathrm{a}$ & $38.7 \mathrm{a}$ & $30.5 a$ & $38.6 \mathrm{a}$ & $34.6 \mathrm{a}$ \\
\hline \multirow{3}{*}{$\begin{array}{r}\text { Svalöv } 0873 \\
\text { Avg. } \\
\end{array}$} & $49.4 \mathrm{~b}$ & $40.3 \mathrm{a}$ & $44.8 \mathrm{~b}$ & $34.1 \mathrm{ab}$ & $38.2 \mathrm{a}$ & $36.1 \mathrm{ab}$ \\
\hline & $38.1 \mathrm{~A}$ & $37.3 \mathrm{~A}$ & 38.9 & $33.2 \mathrm{~A}$ & $39.2 \mathrm{~B}$ & 36.2 \\
\hline & Varieties & Depths & $\mathrm{VxD}$ & Varieties & Depths & $\mathrm{VxD}$ \\
\hline F-value ........ & $\mathbf{x x}$ & NS & NS & $\mathbf{x}$ & $\mathbf{x x x}$ & NS \\
\hline LSD.05 $\cdots \cdots \cdot$ & 7.3 & & & 3.1 & 1.9 & \\
\hline
\end{tabular}

\subsubsection{LAI development}

According to Brown and Blazer (1968) the maximu pasture and hay production is obtained by maintaining the optimal leaf area index (LAI) which is associated with the highest annual yield and the desired growth division rather than with the highest momentary rate of growth. Efficient and beneficial use of LAI in forage production presumes that, in regard to yielding, the optimum LAI is reached quickly and divided evenly throughout the entire stand. The optimum LAI for timothy as indicated by LANGER (1972) is LAI = 6.5 .

The LAI generally describes the formation of the crops dry matter yield rather well (DONALD and Black 1958).

The time of occurrence of the growing season and the growing time influence the realationship between the leaf area index and the dry matter yield. RAININko (1968) obtained the following equation between the spring yield (y) and LAI $(x), \log y=0.1385 x+3.1218$. The equation shows that the yield defined by the LAI occurs in a very narrow area.

\section{Results:}

From the start the Norwegian Engmo variety had the strongest LAI development and the Tarmo variety had the weakest. The LAI's of these two varieties differed significantly (LSD.05 $=0.68$ ) from each other already 16 days after planting (Fig. 5). Also the Tammisto and Nokka varieties experienced more rapid LAI development in the beginning than Tarmo. However, by the first cutting (55 days after planting) the differences had evened out and showed how the varieties had different growth rhythms (Table 4). For the first cutting there were no significant differences between varieties at the deep seeding depth and at the normal depth only the development of the Engmo LAI was significantly faster than the others. During regrowth the intervariety differences at the shallow depth evened out and at the deep depth only Engmo showed that deep planting had retarded its shooting (Table 4). In both the 


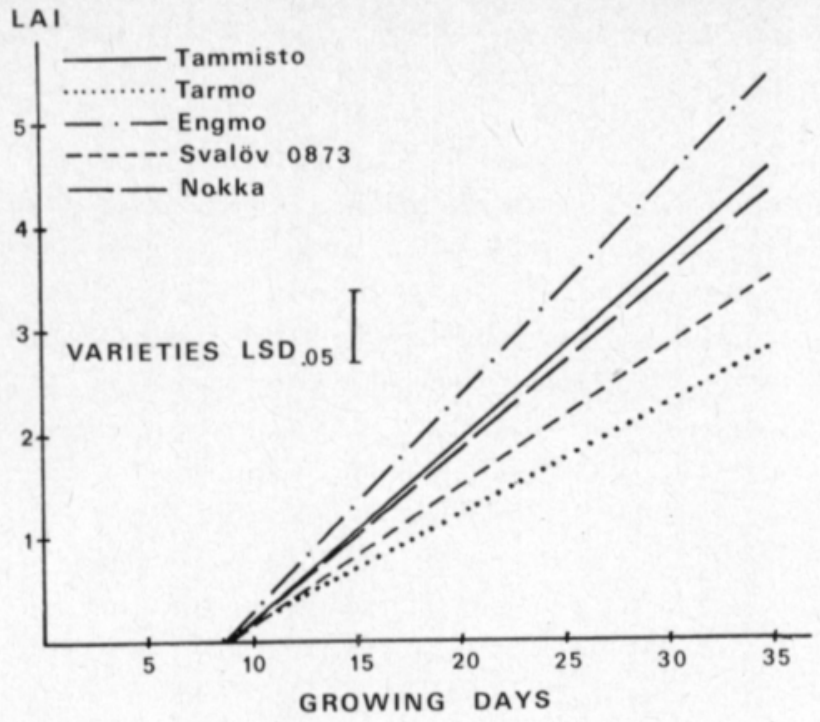

Fig. 5. The relationship between the growing time LAI development in the early development of five timothy varieties.

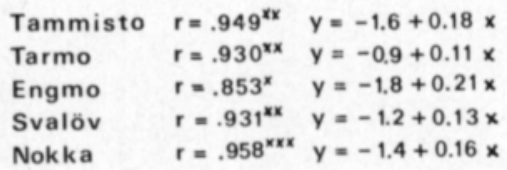

Table 4. LAI of five timothy varieties in the first and second cuts in the greenhouse tests seeded at the depth of $2 \mathrm{~cm}$ and $4 \mathrm{~cm}$.

\begin{tabular}{|c|c|c|c|c|c|c|}
\hline \multirow{3}{*}{ Variety } & \multicolumn{6}{|c|}{ LAI } \\
\hline & \multicolumn{2}{|c|}{ Early development } & \multirow[b]{2}{*}{ Avg. } & \multicolumn{3}{|c|}{ Regrowth } \\
\hline & $2 \mathrm{~cm}$ & $4 \mathrm{~cm}$ & & $2 \mathrm{~cm}$ & $4 \mathrm{~cm}$ & Avg. \\
\hline Nokka ......... & $3.38 \mathrm{a}$ & $2.85 a$ & $3.12 \mathrm{a}$ & $3.89 \mathrm{a}$ & $5.04 \mathrm{~b}$ & $4.46 a$ \\
\hline Tammisto ..... & $3.64 \mathrm{a}$ & $2.98 \mathrm{a}$ & $3.31 \mathrm{a}$ & $3.75 \mathrm{a}$ & $5.20 \mathrm{~b}$ & $4.47 \mathrm{a}$ \\
\hline Tarmo .......... & $3.55 \mathrm{a}$ & $3.01 \mathrm{a}$ & $3.28 \mathrm{a}$ & $3.80 \mathrm{a}$ & $5.05 \mathrm{~b}$ & $4.42 \mathrm{a}$ \\
\hline Engmo ........ & $4.72 b$ & $2.87 a$ & $3.80 \mathrm{a}$ & $3.81 \mathrm{a}$ & $4.49 \mathrm{ab}$ & $4.16 \mathrm{a}$ \\
\hline \multirow[t]{3}{*}{ Svalöv 0873} & $3.59 \mathrm{a}$ & $2.58 \mathrm{a}$ & $3.09 \mathrm{a}$ & $3.64 a$ & $3.92 \mathrm{a}$ & $3.78 \mathrm{a}$ \\
\hline & $3.78 \mathrm{~B}$ & $2.86 \mathrm{~A}$ & 3.32 & $3.78 \mathrm{~A}$ & $4.74 \mathrm{~B}$ & 4.26 \\
\hline & Varieties & Depths & $\mathrm{VxD}$ & Varieties & Depths & $\mathrm{VxD}$ \\
\hline $\begin{array}{l}\text { F-value } \ldots \ldots . \\
\text { LSD. } 05 \ldots \ldots \ldots\end{array}$ & NS & $\begin{array}{l}\mathrm{xxx} \\
0.44\end{array}$ & NS & NS & $\begin{array}{l}\mathbf{x x x} \\
0.46\end{array}$ & NS \\
\hline
\end{tabular}

first and second cuttings the seeding depths differed significantly from each other. In early development of the stand the shallow planting depth allowed rapid LAI formation. However, the more vigorous LAI development observed during regrowth of the varieties at the deep planting depth showed that the most important development stage for growth and development had been reached. 


\subsubsection{Development of dry matter production}

Shoot dry matter production:

The shoot dry matter production of Tammisto, Nokka and Engmo are almost identical (Fig. 6) and follow the shape of the height growth curve. The development of the photosynthetic mechanism in the Tarmo variety and Svalöv line Sv. 0873 is slow, but continues into a later stage than in those varieties where it develops faster, right up to the first cutting (Table 5). The foreign varieties, Engmo and Svalöv, when compared to the domestic ones have noticeably weaker regrowth capabilities, as is reflected in their morphological and physiological characteristics. The development of shoot dry matter production follows the relationships LAI development has to planting depth and cuttings. For the two cuttings there were no significant differences between varieties as to the above ground part of the total dry matter production (Fig. 8). The varieties functioned approximately the same at the shallow and deep planting depths.
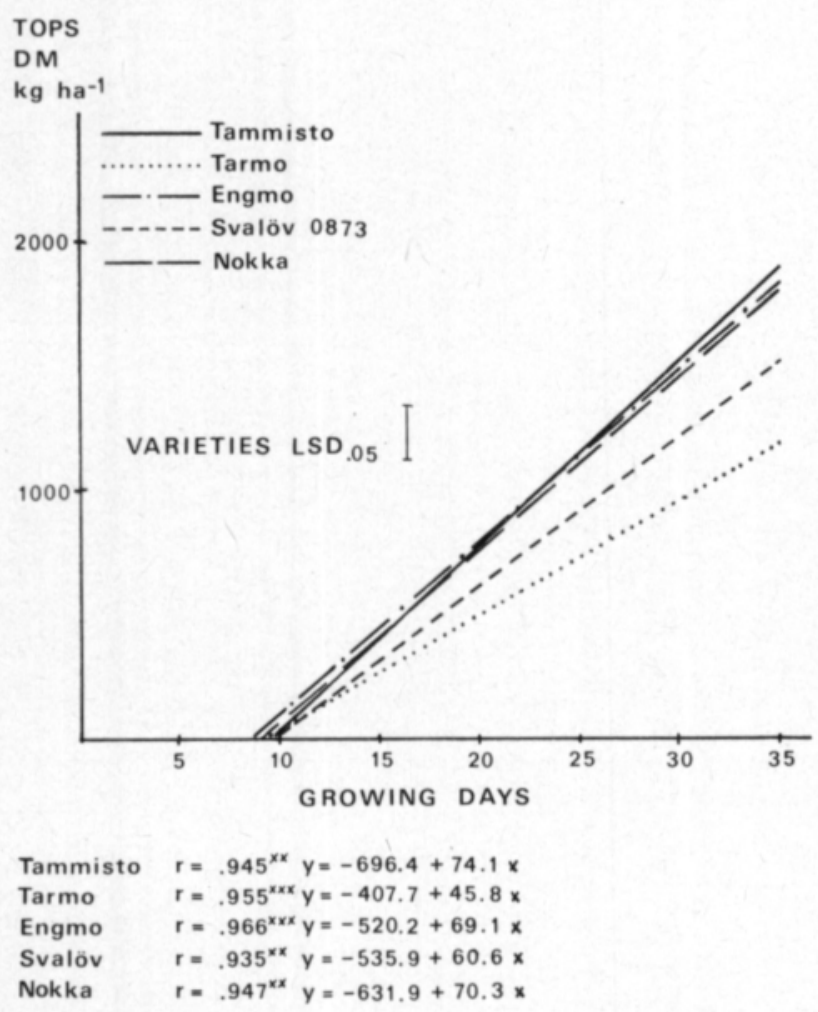

Fig. 6. The relationship between the growing time and the shoot dry matter production $\left(\mathrm{kg} \mathrm{DM} \mathrm{ha}^{-1}\right)$ in the early development of five timothy varieties. 
Table 5. Dry matter yields of five timothy varieties in the first and second cuts in the greenhouse tests seeded at the depth of $2 \mathrm{~cm}$ and $4 \mathrm{~cm}$.

\begin{tabular}{|c|c|c|c|c|c|c|}
\hline \multirow{3}{*}{ Variety } & \multicolumn{6}{|c|}{ DM $\mathrm{kg} / \mathrm{ha}$} \\
\hline & \multicolumn{3}{|c|}{ Early development } & \multicolumn{3}{|c|}{ Regrowth } \\
\hline & $2 \mathrm{~cm}$ & $4 \mathrm{~cm}$ & Avg. & $2 \mathrm{~cm}$ & $4 \mathrm{~cm}$ & Avg. \\
\hline Nokka ......... & $2165 a$ & $2025 a$ & $2100 \mathrm{a}$ & $1860 \mathrm{a}$ & $2225 b$ & $2040 a$ \\
\hline Tammisto .... & $2180 \mathrm{a}$ & $1900 \mathrm{a}$ & $2040 \mathrm{a}$ & $1920 \mathrm{a}$ & $2435 b$ & $2180 \mathrm{a}$ \\
\hline Tarmo ......... & $2300 \mathrm{ab}$ & $1990 \mathrm{a}$ & $2150 \mathrm{a}$ & $1735 \mathrm{a}$ & $2365 b$ & $2050 a$ \\
\hline Engmo ........ & $2700 \mathrm{ab}$ & $1700 \mathrm{a}$ & $2200 \mathrm{a}$ & $1935 \mathrm{a}$ & $2050 \mathrm{ab}$ & $1995 \mathrm{a}$ \\
\hline \multirow[t]{3}{*}{ Svalöv 0873} & $2945 b$ & $2185 a$ & $2565 a$ & $1860 \mathrm{a}$ & $1770 \mathrm{a}$ & $1815 a$ \\
\hline & $2460 B$ & $1960 \mathrm{~A}$ & 2210 & $1860 \mathrm{~A}$ & $2170 \mathrm{~B}$ & 2015 \\
\hline & Varieties & Depths & $\mathrm{VxD}$ & Varieties & Depths & $\mathrm{V} \times \mathrm{D}$ \\
\hline F-value ....... & NS & $\begin{array}{l}x x \\
309\end{array}$ & NS & NS & $\begin{array}{l}x x \\
178\end{array}$ & NS \\
\hline
\end{tabular}

Root dry matter production:

Initial root system development was the same for all varieties with the exception of Tarmo, which, as for height, LAI and shoot development, experienced the slowest development (Fig. 7). However, only Engmo and Tammisto had larger root systems than Tarmo at the time of the second cutting (Fig. 8). The great above ground increase in dry matter experienced by the Svalöv line Sv. 0873 occurred at the expense of root system formation. Engmo's. vigorous root development fits the classification, that it is suited for northern climatic conditions. At the shallow planting depth $(2 \mathrm{~cm})$ both the Nokka variety and the Svalöv line Sv. 0873 had significantly less root dry matter production than the other varieties. There were no significant differences between the varieties at the deeper depth $(4 \mathrm{~cm})$ (Fig. 9).

\section{Shoot-root ratio:}

The shoot-root ratio of timothy varieties provides a clear picture of plant development after seeding (Fig. 8). In general, it can be said that if the regression coefficient is greater than 0.45 , the relative rate of root growth is greater than the relative rate of shoot growth. The Svalöv line Sv. 0873 and the Nokka variety develop their root systems the most vigorously after planting and Tarmo the least. Root growth for Tammisto is almost in the same class as for shoot development (Fig. 8). In later stages the relationship between varieties may change, as is shown in Fig. 9. 


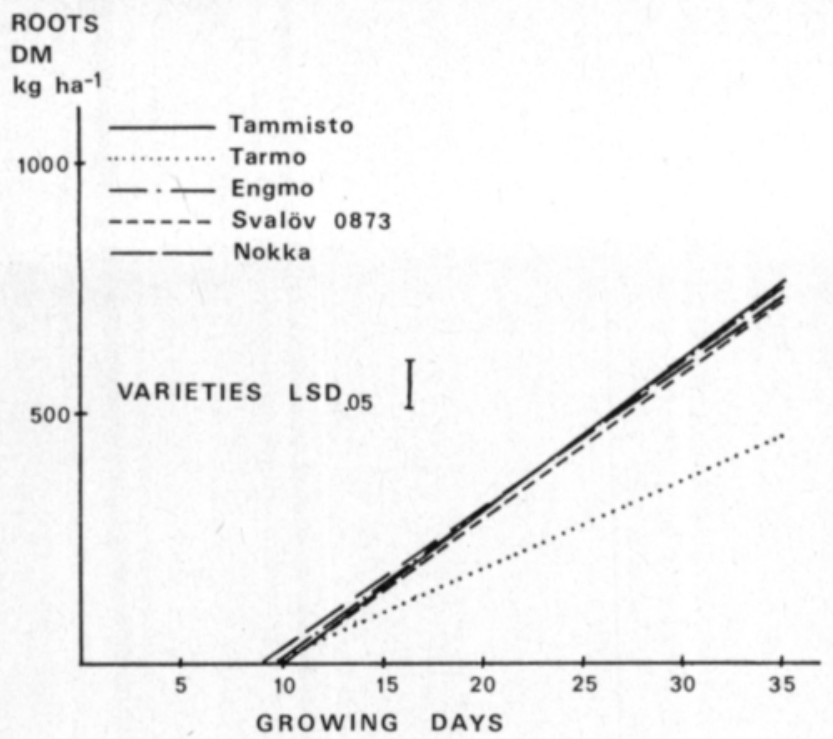

$\begin{array}{ll}\text { Tammisto } & r=.888^{x x} y=-308.4+30.7 x \\ \text { Tarmo } & r=.963^{x x} y=-146.7+17.2 \times \\ \text { Engmo } & r=.919^{x x} y=-277.3+29.6 \times \\ \text { Svalöv } & r=.923^{x x} y=-285.1+28.8 \times \\ \text { Nokka } & r=.946^{x x} y=-247.3+27.8 \times\end{array}$

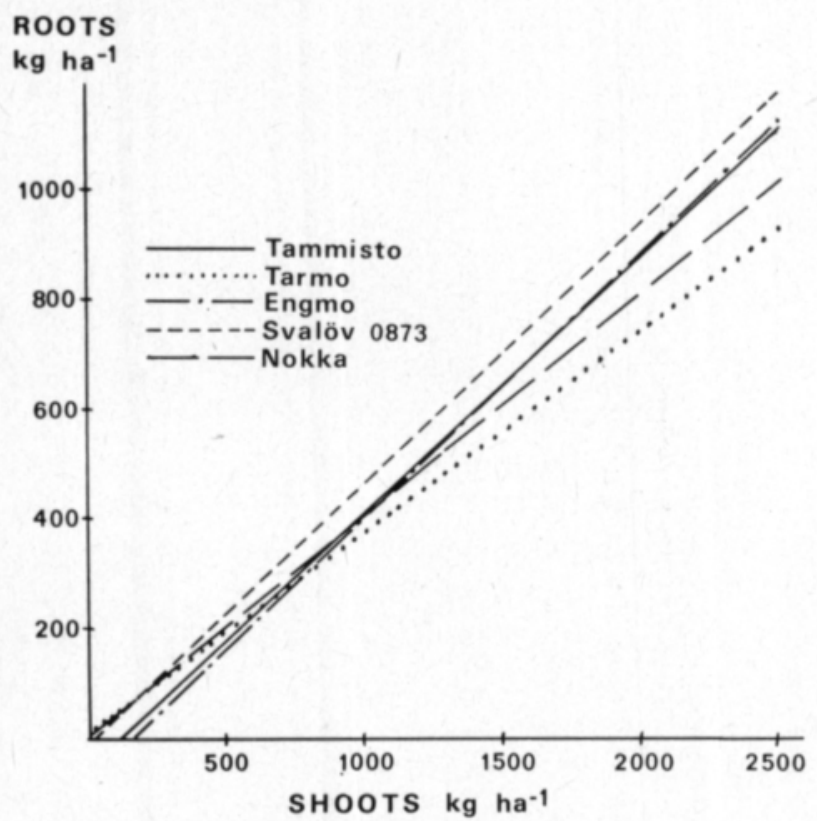

Fig. 7. The relationship between the growing time and the root dry matter production (kg DM ha-1) in the early development of five timothy varieties.
Fig. 8. The relationship between shoot and root dry matter production in the growing phase between $5 \mathrm{~cm}$ and $35 \mathrm{~cm}$ of height for five timothy varieties. 


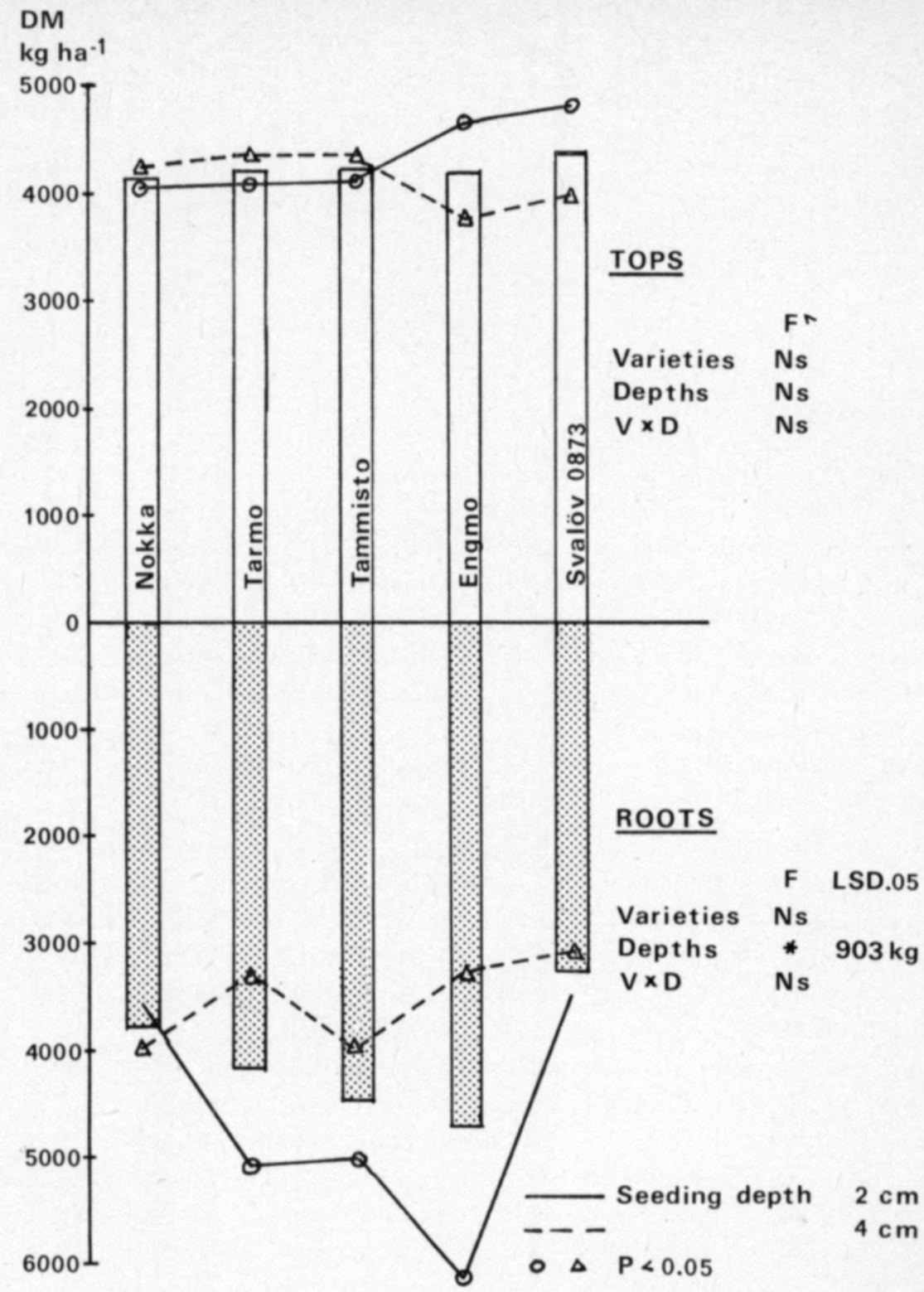

Fig. 9. Shoot and root dry matter production $\left(\mathrm{kg} \mathrm{DM} \mathrm{ha}^{-1}\right)$ of the end of the developmental period of 89 days after seeding and cut twice during that time. 
Table 6. Total production shoot/root of five timothy varieties seeded at two seeding depths of $2 \mathrm{~cm}$ and $4 \mathrm{~cm}$ and cut two times.

\begin{tabular}{|c|c|c|c|}
\hline \multirow{2}{*}{ Variety } & \multicolumn{3}{|c|}{ Seeding depth } \\
\hline & $2 \mathrm{~cm}$ & $4 \mathrm{~cm}$ & Avg. \\
\hline Svalöv $0873 \ldots \ldots \ldots$ & 1.39 & 1.28 & 1.33 \\
\hline Nokka ................... & 1.12 & 1.06 & 1.09 \\
\hline Tammisto ................ & 0.82 & 1.09 & 0.94 \\
\hline Tarmo ................... & 0.79 & 1.32 & 1.00 \\
\hline Engmo ……........... & 0.75 & 1.15 & 0.89 \\
\hline Avg. & 0.93 & 1.17 & 1.03 \\
\hline
\end{tabular}

When the above ground yield of the two cuts is compared to the yield of the root system, it is observed that the root system develops better at a shallow planting depth rather than at a deep one. In addition, the differences between above ground dry matter production are smaller (Fig. 9). At the shallow depth only two varieties had above ground production which surpass below ground production. All five of the varieties had greater shoot than root production at the $4 \mathrm{~cm}$ seeding depth (Table 6). Engmo and Tammisto have the strongest root system development.

\section{2. 4. Discussion}

In the timothy variety tests conducted by the Agricultural Research Centre during the 1960's (Mela and Järvi 1972), the Tammisto, Nokka and Tarmo varieties succeeded equally as well throughout the entire country. The Norwegian Engmo variety, tested by the Plant Husbandry Department in five tests at Tikkurila, was $6 \%$ units less productive than Tammisto, out more productive than Tammisto under northern Finnish conditions. The Svalöv line Sv. 0873 has been in variety tests in Finland during 1975-77. It is considered as a southern Finnish variety. Antila (1979) stated that in southern Finland Sv. 0873 was $2-9 \%$ units better than Tammisto, but $10-14 \%$ units worse under mid and northern Finnish conditions. The biggest advantage of the Svalöv line Sv. 0873 has been its good regrowth for a second cutting.

The greenhouse tests show that, despite growth rhythm differences, the three most important domestic timothy varieties produce approximately the same amount of dry matter in the first and second cuts as well as in total yield. These results correspond with those of field tests (RaIninko 1970). The foreign Engmo variety and Svalöv line Sv. 0873, because of their classification as hay types, produced more in the first cut than the Finnish varieties did. A significant observation was that planting depth was of importance only in the first cutting. The second cut's yield level was determined primarily by the production level of former cut. The correlation was negative. Of the five varieties investigated Engmo had the greatest root production as reflected by its good wintering characteristics and suitability for northern climatic conditions. Also a low shoot/root ratio describes these same features. Engmo's good root growth most likely also stimulated a faster LAI development than was found for the other varieties. 


\section{3. Summary and conclusions}

The tests dealing with the growth and development of timothy were divided into two parts, a literature study and a greenhouse study.

In the literature study the success of the three most important Finnish varieties, Tammisto, Nokka and Tarmo, under various growing conditions was tested according to the FinLAY and WiLkinson procedure (1963). The test material comprised 91 Hankkija Plant Breeding Institute and Agricultural Research Centre comparisons of timothy varieties.

The greenhouse study included the aforementioned three domestic varieties as well as the northern hay type, Engmo, and the more southern hay type, Svalöv line Sv. 0873. This part of the study was divided into two series: Serie I dealt with the primary development of the varieties and Serie II also included regrowth capabilities.

The following conclusions can be drown from the study:

1. All of the three most important Finnish timothy varieties had the same dry matter and protein production capabilities.

2. Of the three varieties, Tammisto represents the most demanding variety as it had regression coefficients greater than 1 for both dry matter and protein production.

3. The Nokka variety can be considered a general dry matter producer and a thriving raw protein producer. The regression coefficients were approximately 1 and less than 1 , respectively.

4. The Tarmo variety is the only one considered thriving for both dry matter and protein production because it had respective regression coefficients less than 1 and a relatively high yielding level.

5. The greenhouse experiment showed that the Tarmo variety had the slowest development rhythm of the domestics, and Sv. 0873 the slowest of the foreign ones. The differences in development rhytms evened out by the time of the first cut.

6. The regrowth capabilities of the hay types, Engmo and Svalöv line Sv. 0873 , were less than those of the domestic varieties.

7. Engmo, being best suited for northern climatic conditions, had the best root growth and the southern variety, Sv. 0873, had the weakest. Large root production represented rapid development of LAI.

8. When germinating, the planting depth had significance only in the first cut. The regrowth yield was primarily effected by the size of the first yield. The yields were negatively correlated.

Acknowledgements. The study was made possible through funds provided by farmer Nokka which were used to cover expenses incurred while collecting the material. My sincere thanks to farmer Nokka, the Hankkija Plant Breeding Institute and the various research units of the Agricultural Research Centre which provided material for this investigation. The help of Mr. MARKKU KIVEL $\AA$, in collecting the material and assisting with the arrangements of the greenhouse studies was greatly appreciated. 


\section{REFERENCES}

AhLBERG, E. 1964. Kylvösyvyyden vaikutus nurmiheinälajiemme siemenien orastumiseen. Kylvösiemen 3: 14-14.

AntılA, S. 1973. Apila, apila-heinä vai puhdas heinä. Käyt. Maamies 5: 36-38.

- 1976. Mihin aikaan typpi rehunurmille. Käyt. Maamies 7:10-11.

- 1979. Timotei Sv. 0873 Länsi-Hahkialan tutkimuslaitos. Julkaisematon yhteenveto.

Brown, R. H. \& Blazer, R. E. 1968. Leaf area index in pasture growth. Herb. Abstr. 38: 1-9.

Donald, C. M. \& Black, J. N. 1958. The significance of leaf area in pasture growth. Herb. Abstr. 28: 1-6.

Elonen, P. 1974. Sadetus satovaihtelujen tasoittajana. Käyt. Maamies 3:16-20.

Essen, M. von 1913. Tutkimuksia rehukasviviljelyksen alalta I. 282 p. Helsinki.

Finlay, K. W. \& Wilkinson, G. N. 1963. The analysis of adaptation in a plant breeding programme. Aust. J. Agric. Res. 14: 742-754.

Наккоц., Н. 1978. Nurmikasvikokeiden tuloksia. Maatalouden tutkimuskeskuksen PohjoisPohjanmaan koeaseman tiedote No. 5. 29 p.

HAN, H. J., YANG, J. S., LeE, J. Y. \& PARK, K. J. 1977. Influence of light intensity on the growth and yields of Dystaenia takesimana and two pasture species. Res. Rep. off. Rur. Deval. Min. Agric. Fish. 19: 123-128.

HARI, P. \& Leikola, M. 1974. Further development of the dynamic growth model of plant height growth. Flora B1. 163: 357-370.

- , KellomäкI, S. \& VUокко, R. 1977. A dynamic approach to analysis of height growth of plants. Oikos 28: 234-241.

Huoкuna, E. 1970. Keski- ja Pohjois-Suomen mahdollisuuksista tuottaa korkealaatuista nurmirehua. Hankkijan siemenjulkaisu 1970: 172-177.

Kvet, J., Ondok, J. P., Negas, J. \& Jarvis, P. G. 1971. Methods of growth analysis. Plant photosynthetic production. p. 343-391. Ed. Sestak, Z., Catsky, J. \& Jarvis, P. G. The Netherlands 1971.

LAINE, T. 1966. Heinäkasvien typpilannoitus. Maatal. ja koet. 20: 69-79.

LANGer, R. H. M. 1958. A study of growth in swards of Timothy and Meadow fescue. I. Uninterrupted growth. J. Agric. Sci. 51: 347-352.

- 1972. How grasses grow. 57 p. Clowes \& Sons. London 1972.

Manner, R., Multamäкi, K. \& Ravatti, S. 1966. Plant-breeding work with grassland plants in Finland. Proc. 10th Int. Grassl. Congr. 1966: 758-761.

MelA, T. 1975. Sadetuksen vaikutus nurmen satoon ja sen laatuun. Kehittyvä Maatalous 23: $25-30$.

- \& JÃRvı, A. 1972. Timoteilajikkeet 1960-luvun lajikekokeissa. Erip. Koetoim. ja Käyt. 1972: 10.

Moore, R. P. 1943. Seedling emergence of small seeded legumes and grasses. J. Amer. Soc. Agron. 35: $370-381$.

Mukula, J. 1973. Nurmiviljelyn merkitys Suomen maataloudessa. Erip. Maaseudun Tulev. $115 / 73$.

Mulтамӥкı, K. 1962. Nurmikasvien itäminen alhaisissa lämpötiloissa. Koetoim. ja Käyt. $1: 4$.

North, J. J. 1961. Sadetus voi kaksinkertaistaa nurmen tuoton. Suomalainen Farmari 3: $22-24$.

OLoFsson, S. 1962. Tillväxt och kemisk sammansättning hos några vallgräs under våren och försommaren. Stat. Jordbr.förs. Medd. 135: 1-123.

Pohjakallio, O. \& Salonen, M. 1956. Orientoitumisvaiheen tulokset Muddusniemen koetilan nurmikasvitutkimuksissa. J. Scient. Agric. Soc. Finl. 28:1-17.

Pohjonen, V. \& Hari, P. 1973. A dynamic model of crop growth rate of Italian ryegras after cutting. Acta Agr. Scand. 23: 121-126.

Rarninko, K. 1968. The effects of nitrogen fertilization, irrigation and number of harvestings upon leys established with various seed mixtures. Acta Agr. Fenn. 112: 1-136.

- 1970. Timotei. Hankkijan Siemenjulkaisu 1975: 80-83.

— \& JuUrı, T. 1975. Timotei. Hankkijan Siemenjulkaisu 1975: 81-84. 
Ravantri, S. \& Ravantri, T. 1955. Timotei. Hankkijan Siemenjulkaisu 1955: 70-73.

- 1960. Timotei. Hankkijan Siemenjulkaisu 1960: 102-109.

- 1963. 50 vuotta nurmikasvien jalostustyötä. Karjatalous 39: 106-109.

- 1965. Timotei. Hankkijan Siemenjulkaisu 1965: 74-86.

REKUNEN, M. 1979. Sopeutumisesta kasvinjalostusongelmana. Helsingin yliopisto, Kasvinviljelytieteen laitos, Julkaisuja 5: 19-37.

SALONEN, M. 1963. Eri typpilannoitemäärien vaikutuksesta heinäsatojen määrään ja laatuun. Leipä leveämmäksi $3: 5-8$.

SrmolA, E. F. 1926. Maanlaatujen ja kosteussuhteiden vaikutuksesta eräiden viljelykasvien morfologisiin ominaisuuksiin, satoihin ja veden kulutukseen. Valt. Maatal.koet. Julk. 2.

Teitrinen, P. 1958. Amerikkalaisen timotein viljelyarvosta Suomessa. Valt. Maatal. koet. Tied. $237: 1-13$.

VALLE, O. 1929. Nurmikasvit. Maa ja Metsä 2: 747-798.

- 1947. Niittynurmiviljely. Rehunviljelyopas AIV-rehun valmistajia varten. p. 42-88. Helsinki.

Williams, S. S. 1954. The effect of depth of sowings and moisture on the germination and seedling development of Phleum pratense. J. Econ. 42: 2: 445-459.

Virtanen, A. I. 1932. Tutkimuksia niittoajan vaikutuksesta sadon suuruuteen ja sen laatuun. Valtion Lab. Julk. 24 p. Helsinki.

Ms received March 14, 1980.

\section{SELOSTUS}

\section{Timoteilajikkeiden kasvusta ja kehityksestä}

SePPo Pulli

Helsingin yliopisto, Kasvinviljelytieteen laitos, 00710 Helsinki 71

Timotein kasvuun ja kehitykseen liittyvä tutkimussarja käsitti kirjallisuustutkimuksia ja kasvihuonetutkimuksia. Kirjallisuustutkimuksissa tarkasteltiin kolmen tärkeimmän suomalaisen timoteilajikkeen, Tammiston, Nokan ja Tarmon kuiva-ainetuotanto- ja valkuaisainetuotantokykyä.

Testauksessa lajikkeen sadontuottoa verrattiin tutkittujen lajikkeiden satojen keskiarvoon FINLAYN ja WILKıNSONın esittämällä tavalla. Kuiva-aineen tuotannon vertailussa mainitut lajikkeet esiintyivät samanaikaisesti 62 kertaa Etelä-Suomen olosuhteissa ja 29 kertaa PohjoisSuomen olosuhteissa. Raakavalkuaistuotantoa voitiin testata vain Etelä-Suomen olosuhteissa yhteensä 37 kokeessa.

Kasvukammiotutkimukset käsittivät kaksi koesarjaa koejäseninä em. lajikkeiden lisäksi norjalainen Engmo ja Svalövin eteläinen linja Sv. 0873. Kasvukammiotutkimuksessa selvitettiin timoteilajikkeiden alkukehitystä kasvupituuteen $35 \mathrm{~cm}$. Tutkimuskohteina olivat kasvuston pituuden ja lehtialan kehitys sekä versojen ja juurten kasvuun liittyvät tutkimukset. Kasvukammiotutkimuksessa seurattiin lisäksi viiden timoteilajikkeen kasvua kylvöstä ensimmäiseen niittoon sekä niiton jälkeistä jälkikasvua. Kasvuun vaikuttavina tekijöinä oli lajikkeiden lisäksi kylvősyvyys. Tutkittavina parametreinä olivat kasvuston pituus, LAI, versojen ja juurten kehitys sekä verso/juuri suhde.

Tuloksista todettakoon, että tutkituilla kolmella suomalaisella timoteilajikkeella oli samanlainen kuiva-aineen ja valkuaisen tuottokyky. Kotimaisista lajikkeista Tammisto edusti suhteellisen vaateliasta tyyppiä, jolla sekä kuiva-aineen että raakavalkuaisen tuotannossa oli regressiokerroin suurempi kuin yksi. Nokan timoteita voidaan kuiva-aineen tuotannossa kutsua yleislajikkeeksi ja raakavalkuaisen tuotannossa viihtyväksi lajikkeeksi. Kuiva-aineen tuotannossa oli Nokan regressiokerroin noin yksi ja valkuaisen tuotannossa alle yhden. Tarmo 
osoittautui sekä energian että valkuaisen tuottajana viihtyväksi lajikkeeksi ja sillä oli tutkituista lajikkeista alhaisin regressiokerroin.

Kasvukammiotutkimuksissa todettiin, että Tarmolla ja Svalövin linjalla Sv. 0873 oli muista lajikkeista poikkeavasti erittäin hidas alkukehitys. Samat lajikkeet kehittyivät kuitenkin muita nopeammin nopean kasvun vaiheessa. Heinätyypeillä Engmo ja Sv. 0873 jälkikasvukyky oli suomalaisia lajikkeita heikompi. Pohjoisiin olosuhteisiin sopeutuneella Engmolla oli paras juurituotanto ja eteläisiin oloihin jalostetulla Sv. 0873:lla heikoin. Engmon suurta juurituotantoa edisti nopea LAI:n kehittyminen.

Tutkimuksissa ilmeni selvästi, että jos siemen yleensä taimettuu, kylvösyvyydellä on merkitystä vain ensimmäisessä niitossa. Jälkikasvun sadon suuruuteen vaikuttaa ensisijaisesti edellisen niiton suuruus. Niittojen sadot ovat negatiivisessa korrelaatiossa. 